\section{BRSMG Alterosa: Rice cultivar for lowland cultivation in Minas Gerais}

\section{Plínio César Soares ${ }^{1 *}$, Moizés de Sousa Reis ${ }^{2}$, Vanda Maria de Oliveira Cornélio ${ }^{2}$, Paula Pereira Torga ${ }^{3}$, Francisco Pereira Moura Filho ${ }^{3}$, Priscila Zaczuk Bassinello ${ }^{3}$ and Aurinelza Batista Teixeira Condé}

\begin{abstract}
The lowland rice breeding program, developed in Minas Gerais state, has as basic objective to release new commercial cultivars. In this way, this program is making available a new cultivar named BRSMG Alterosa, which has as main characteristics: high grain yield, high tillering, medium cicle, diseases tolerance and high grain quality. It was recommended in 2017.
\end{abstract}

Keywords: Oryza sativa, genetic breeding, variety.

\section{INTRODUCTION}

In recent years, rice production in Brazil has been sufficient to supply the domestic market. In the $2017 / 2018$ growing season, the output of this cereal was about 12.06 million tons. Generally speaking, rice cultivation is spread throughout the entire country, but a major part is concentrated in the CenterSouth Region, where approximately 10.4 million tons were harvested in the said season (CONAB 2018).

Minas Gerais is leading in rice production in the Southeast Region. In the 2017/2018 growing season, the regional yield mean was 4,235 $\mathrm{kg} \mathrm{ha}^{-1}$, grown on an area of 3,347 thousand hectares. In other words, the rice-producing area decreased, accompanied by a production increase over the years. This trend was observed from 1976 to 2018, culminating in significant yield increases of the crop in that period. The mean yield in the growing season of 1976/1977 was $897 \mathrm{~kg} \mathrm{ha}^{-1}$, but nowadays around $4,235 \mathrm{~kg} \mathrm{ha}^{-1}$ (CONAB 2018).

One of the main factors contributing to improve the rice production was the planting of improved cultivars, adapted to each cultivation modality. The reason is that the developed technology (in the form of new cultivars) is cheap and easily implemented by farmers, providing significant gains in crop yields (Soares et al. 2017).

The process of indicating rice cultivars for commercial plantations is continuous and dynamic, i.e., periodically, new cultivars are recommended instead of those that are less productive and/or with less commercial acceptance. Along this line of action, the research consortium between EPAMIG and Embrapa Rice and Beans tests several lines and cultivars of the irrigated rice breeding program every year, at different locations in Minas Gerais, in order to offer rice farmers improved options, to be able to choose suitable cultivars for their crops grown in lowlands (Soares et al. 2008).
Crop Breeding and Applied Biotechnology 19(4), 462-465, 2019 Brazilian Society of Plant Breeding. Printed in Brazil http://dx.doi.org/10.1590/198470332019v19n4c65 
As a recent contribution of this integrated research, a new irrigated rice cultivar was released for rice production in Minas Gerais, in 2017, under the name BRSMG Alterosa. This cultivar is the $18^{\text {th }}$ flooded rice variety released by the cited research program. It is recommended for commercial cultivation throughout the state of Minas Gerais, under irrigation by continuous flooding in lowlands.

\section{MATERIAL AND METHODS}

A total of 152 elite rice lines of the irrigated rice breeding program of the State of Minas Gerais were evaluated for grain yield $\left(\mathrm{kg} \mathrm{ha}^{-1}\right)$ and several other traits, from 2004/2005 to 2015/2016. In each growing season, tests for value of cultivation and use (VCU) were performed with 25 genotypes (control lines and cultivars) on experimental fields of

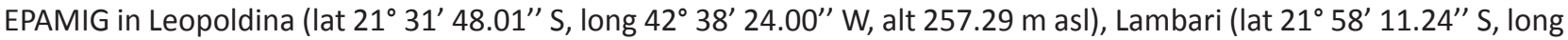
$45^{\circ} 20^{\prime} 59.60^{\prime \prime} \mathrm{W}$, alt $887.55 \mathrm{~m}$ asl) and de Nova Porteirinha (lat $15^{\circ} 48^{\prime} 0.77^{\prime \prime} \mathrm{S}$, long $43^{\circ} 17^{\prime} 59.09^{\prime \prime} \mathrm{W}$, alt $533.77 \mathrm{~m}$ asl). Due to environmental problems, all trials of the 2008/2009 and 2012/2013 growing seasons were disregarded. The experiment was arranged in a randomized block design, with three replications. The experimental plots consisted of five 5-m long plant rows, spaced $30 \mathrm{~cm}$ apart $\left(5 \mathrm{~m} \times 1.5 \mathrm{~m}=7.50 \mathrm{~m}^{2}\right)$. For evaluation, the four central meters of the three internal rows $\left(4 \mathrm{~m} \times 0.9 \mathrm{~m}=3.60 \mathrm{~m}^{2}\right)$ were taken into consideration.

In the experimental area of Leopoldina, the seedlings were grown in nurseries and later transplanted to the field, at a plant spacing of $0.20 \mathrm{~m}$. At the other locations, the trials were planted by direct sowing in the planting row, at a density of 300 seeds $\mathrm{m}^{-2}$. The tests were carried out on lowland soils with continuous flood irrigation. Irrigation was initiated around 10 to 15 days after seedling emergence, in the case of seed planting, or when the seedlings were established in the soil. Irrigation was discontinued about 10 days before maturation of the latest line represented in the test.

The following key traits were evaluated: leaf color; pubescence; flag leaf angle; tillering capacity; glume color; apex color at maturity; presence of awns; natural grain loss; grain yield; plant height; cycle length until flowering and until maturation; lodging; disease incidence; husked grain size; 1000-seed weight; industrial yield; grain class; gelatinization temperature; and amylose content. These evaluations were carried out according to the Handbook of Research Methods in Rice published by Embrapa Rice and Beans (EMBRAPA 1977).

\section{Genealogy and breeding method}

Cultivar BRSMG Alterosa was derived from a single cross, involving the genotypes P3299F4-33 and CNAx7852F4-1-2-B, with a view to increasing blast resistance, rusticity, yield potential and grain quality. The cross was made at Embrapa Rice and Beans in 1996 and recorded in the book crosses of this unit as BRA 02691. On the other hand, CNAx7852F4-1-2-B was the result of multiple crosses involving several genotypes of irrigated and also of ranifed rice.

The evaluations of line BRA 02691, from which BRSMG Alterosa was derived in the $F_{2}$ to $F_{5}$ segregating generations, were carried out by rice breeders of Embrapa Rice and Beans, using genealogical and mass selection techniques. As of 2002/2003, the line was included in the National Network of Line Evaluation by the Test of Observation of Tropical Irrigated Rice Lines, where it was tested in Minas Gerais and other states.

Subsequent assessments were carried out in the State, in Preliminary Comparative tests in the 2003/2004 growing season and in Advanced Comparative VCU trials, over 10 growing seasons (2004/2005 to 2015/2016), with a total of 21 trials. The results demonstrated the superior performance of 'BRSMG Alterosa' over the control cultivars, recommending this cultivar for cultivation under continuous flooding in all physiographic regions of Minas Gerais, as of 2017.

Cultivar BRSMG Alterosa was registered in 2018 by the National Service of Registration of Cultivars of the Ministry of Agriculture (SNPC/MAPA), no. 37,884. It is adapted to all physiographic regions of Minas Gerais, suited for irrigated rice cultivation in lowlands (Soares et al. 2018).

\section{PERFORMANCE TRAITS}

In twenty-one VCU trials, carried out from 2004/2005 to 2015/2016, at three localations of Minas Gerais (Lambari, Leopoldina and Nova Porteirinha), BRA 02691 porduced excellent grain yields, with a weighted mean of 6,544 kg ha-1 (Table 1). Comparing it with the yield of the five control cultivars evaluated in the VCU tests, the statistical mean of 
Table 1. Grain yield means ( $\mathrm{kg} \mathrm{ha}^{-1}$ ) of cultivar BRSMG Alterosa and control cultivars in the VCU trials, in Minas Gerais, from $2004 / 2005$ to $2015 / 2016$

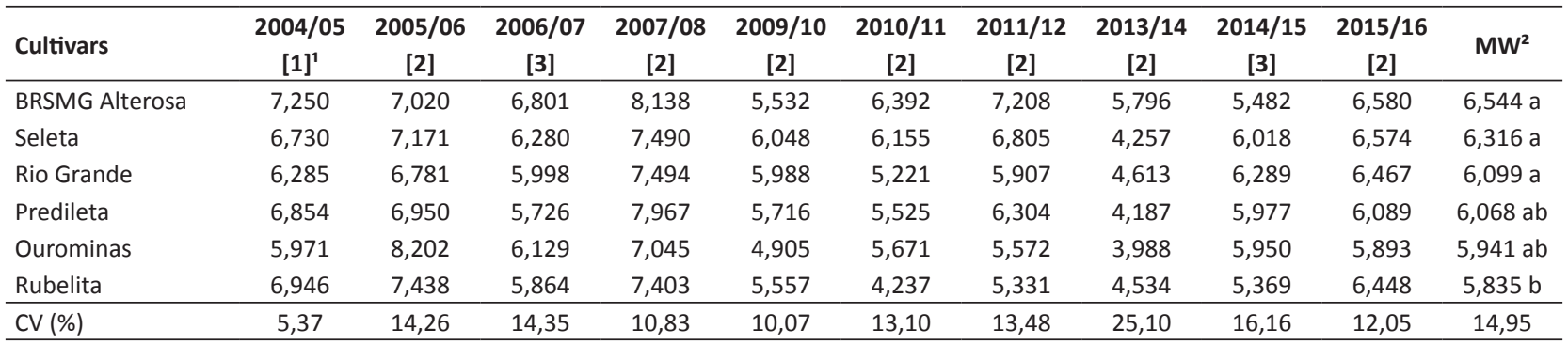

1 - Number of tests carried out in the respective growing season; 2 - Means followed by the same letter in a column do not differ statistically by the Scott-Knott test at $5 \%$ probability. MW - Mean weight

the line exceeded that of BRSMG Rubelita $\left(5,835 \mathrm{~kg} \mathrm{ha}^{-1}\right)$. The yield means of the other controls (BRSMG Seleta, Rio Grande, BRSMG Predileta, and Ourominas) did not differ from that of BRA 02691. Due to the excellent performance of line BRA 02691 in the VCU tests, along with the good performance in terms of resistance to blast and other rice diseases, lodging resistance, the good cooking quality and industrial grain quality, it was possible to introduce this line as a new rice cultivar for irrigated cultivation in the lowlands of Minas Gerais, called BRSMG Alterosa. It was pre-relaesed on a field day in March/2017, in HeliodoraSul de Minas, MG.

\section{PLANT CHARACTERISTICS}

The main botanical, morphological and phenological characteristics of cultivar BRSMG Alterosa are listed in Table 2. This modern rice cultivar has upright leaves, normal green color, a high tillering capacity, medium plant height and lodging resistance. It is moderately resistant to the main rice diseases (leaf and panicle blast, brown spot, grain spot and leaf scald). At maturation, the glumes are straw-colored and the apex yellow, with or without short awns. It reaches full maturation after around 135 days.

\section{GRAIN CHARACTERISTICS}

The cooking quality of cultivar BRSMG Alterosa grains was analyzed at the Laboratory of Embrapa Rice and Bean (Table 3). An intermediate/low amylose content and intermediate gelatinization temperature $(G T=4.0)$ were found, indicating excellent cooking quality The grains have a translucent apperance and are loose and soft after cooking, owing to the gelatinization temperature, meeting the requirements of the consumer markets of Minas Gerais and across Brazil. 'BRSMG Alterosa' has an excellent yield of whole-grain rice after processing (above 55\%), assessed as described by Vieira and Rabelo. The cultivar has long, fine grains of the class long-grain rice ("agulhinha"), the most popular type of this cereal on the Brazilian market. To classify rice as long-grain rice, at least $80 \%$ must be whole grains
Table 2. Plant characteristics of rice cultivar BRSMG Alterosa

\begin{tabular}{|c|c|}
\hline Plant characteristics & Description \\
\hline Leaf color & Green \\
\hline Auricle color & Light green \\
\hline Ligule color & Colorless to green \\
\hline Leaf blade pubescence & Mean \\
\hline Flag-leaf angle & 90 \\
\hline Stem length & Medium $(83.0 \mathrm{~cm})$ \\
\hline Stem thickness & Thick (6 mm) \\
\hline Tiller angle & Right \\
\hline Internode color & Light green \\
\hline Panicle length & Short $(19.0 \mathrm{~cm})$ \\
\hline Panicle type & Compact \\
\hline Panicle exertion & Mean \\
\hline Natural grain loss & Intermediate \\
\hline \multicolumn{2}{|l|}{ Spikes: } \\
\hline Apicule color & Green \\
\hline Glume pubescence & Mean \\
\hline Apicule color at flowering & Green \\
\hline Apicule color at maturity & Yellow \\
\hline Glume color & Straw/Golden \\
\hline Tillering & High \\
\hline Complete maturation cycle & Medium (130-140 days) \\
\hline Plant height & 95 to $100 \mathrm{~cm}$ \\
\hline Lodging & Resistant \\
\hline \multicolumn{2}{|l|}{ Disease reaction: } \\
\hline Leaf blast & Moderately resistant \\
\hline Panicle blast & Moderately resistant \\
\hline Brown Spot & Moderately resistant \\
\hline Grain spot & Moderately resistant \\
\hline Leaf scald & Moderately resistant \\
\hline
\end{tabular}


with a length of at least $6.00 \mathrm{~mm}$; a maximum thickness of $1.90 \mathrm{~mm}$, and a grain length/width ratio of $>2.75$ after polishing (Vieira and Rabelo 2006).

\section{PRODUCTION OF FOUNDATION SEED}

Foundation seed of cultivar BRSMG Alterosa is produced by the Agriculture and Livestock Research Institute of Minas Gerais (EPAMIG) and the Brazilian Agricultural Research Corporation (Embrapa).

\section{ACKNOWLEDGEMNTS}

The authors would like to thank the Minas Gerais State Research Foundation (Fapemig) and the National Council for Scientific and Technological Development (CNPq) for funding the research projects of irrigated rice breeding in Minas Gerais and for granting awards for excellence in research and scientific initiation scholarships.

\section{TRIBUTE}

A few words of eternal gratitude for the friendship, companionship, trust and the impressive commitment to research of the great researcher of Embrapa Rice and Beans, Dr. Orlando Peixoto de Morais (in memoriam) should be mentioned here. We will bear and honour him in our memory as a unique human and professional, an example of simplicity, ethics and competence.

\section{REFERENCES}

CONAB (2018) Acompanhamento da safra brasileira de grãos, v.6, n.2Safra 2018/19. Available at: <www.conab.gov.br/info-agro/safras/ grãos>. Accessed on December 06, 2018.

EMBRAPA (1977) Manual de métodos de pesquisa de arroz: 1a aproximação. Embrapa Arroz e Feijão, Goiânia, 106p.

Soares PC, Soares AA, Reis MS, Cornélio VMO, Condé ABT and Torga PP (2018) Adaptabilidade e aceitabilidade das cultivares de arroz recomendadas para Minas Gerais, por produtores, industriais e consumidores. Informe Agropecuário 39: 35-46.
Table 3. Grain characteristics of the cultivar BRSMG Alterosa

\begin{tabular}{lc}
\hline Traits & Values \\
\hline Husked grain length & $7.53 \mathrm{~mm}$ \\
Husked grain width & $2.10 \mathrm{~mm}$ \\
Grain length/width ratio & 3.58 \\
Grain shape & Stretched \\
Grain class & Long-thin \\
1000-seed weight & $25.9 \mathrm{~g}$ \\
Amylose content & Intermediate/low \\
Gelatinization temperature (GT) ${ }^{1}$ & 4.0 (intermediate) \\
Whole-grain yield & $>55 \%$ \\
Chalkiness index ${ }^{2}$ & 3.0 \\
\hline
\end{tabular}

${ }^{1} \mathrm{High}=$ scores 2 and 3 ; intermediate $=$ scores 4 and 5 ; low $=$ scores 6 and $7 ;{ }^{2}$ Excellent = score 1 ; good $=$ score 2 ; regular $=$ score 3 ; poor = score 4 ; extremely poor= score 5. Vieira AR, Araújo RF, Baffa DCF, Costa JC, Ribeiro RM and Silva FL (2008) BRSMG Predileta: irrigated rice cultivar for lowlands in Minas Gerais, Brazil. Crop Breeding and Applied Biotechnology 8: 251-254.

Soares PC, Cornélio VMO, Reis MS, Soares AA, Morais OP, Moura Filho FP and Torga PP (2017) BRSMG Rubelita: irrigated rice cultivar for lowlands in the state of Minas Gerais. Crop Breeding and Applied Biotechnology 17: 180-183.

Vieira NRA and Rabelo RR (2006) Qualidade tecnológica In Santos AB, Stone LF and Vieira NRA (eds) A cultura do arroz no Brasil. Embrapa Arroz e Feijão, Santo Antônio de Goiás, p. 969-1005.
Soares PC, Soares AA, Cornélio, VMO, Reis MS, Morais OP, Cutrim VA, 